\title{
PENINGKATAN KINERJA MELALUI SERVANT LEADERSHIP, DISIPLIN KERJA DAN KEPUASAN KERJA PADA DINAS PERTANIAN KABUPATEN DEMAK
}

\author{
Evvien Akbar \\ Nurhidayati \\ Universitas Islam Sultan Agung Semarang \\ evvienakbar@gmail.com
}

\begin{abstract}
This study aims to analyze the influence of servant leadership and work discipline on employee performance with job satisfaction as intervening variable. Population in this research is employees who work at Agriculture Department of Demak Regency for 121 employees, with total sample of 55 employees. The sampling technique used in this study is Proportional Random Sampling. The analysis tool is the path analysis, where previously tested the validity and reliability as well as the classical assumption test. Test results show that servant leadership and work discipline proved to have a positive and significant impact on job satisfaction. Servant leadership proved to have a positive and significant influence on employee performance, can be interpreted that the higher servant leadership, the more leaders are able to serve their subordinates sincerely, so that it will have an impact on the high performance of employees. Work discipline proved to have a positive and significant effect on employee performance. Job satisfaction has a positive and significant effect on employee performance, meaning that the higher level of job satisfaction of employees, it will certainly have an impact on the high performance of employees.
\end{abstract}

Keywords: Servant leadership, work discipline, job satisfaction and employee performance.

\section{PENDAHULUAN}

Kinerja merupakan gambaran mengenai tingkat pencapaian pelaksanaan suatu kegiatan atau program atau kebijakan dalam mewujudkan sasaran dan tujuan dalam suatu organisasi. Mengacu dari pendapat diatas dapat disimpulkan bahwa kinerja adalah hasil kerja yang dicapai oleh seorang pegawai melalui suatu pelaksanaan pekerjaan atau tugas tugas yang dibebankan kepadanya sesuai dengan waktu yang telah ditentukan, bermutu, dan tepat mengenai sasaran dengan selalu mengikuti metode yang telah ditetapkan (Mahsun, 2006). Kinerja pegawai yang baik adalah gambaran dari kepuasan kerja yang didapatkan ketika melakukan pekerjaan yang mereka sukai.
Kepuasasan kerja pegawai merupakan faktor penting dalam suatu organisasi yaitu untuk menunjang tercapainya tujuan organisasi. Kepuasan kerja pegawai dapat dilihat tidak hanya saat melakukan pekerjaan, tetapi terkait juga dengan aspek lain seperti interaksi dengan rekan kerja, atasan, mengikuti peraturan, dan lingkungan kerja (Hariandja, 2009). Kepuasan kerja mencerminkan perasaan seseorang terhadap pekerjaannya yang dapat terlihat dari sikap terhadap pekerjaan dan segala sesuatu di lingkungan pekerjaan. Faktor penting dalam suatu organisasi yaitu kepuasan kerja yang dapat menunjang tercapainya tujuan organisasi. Pencapaian tujuan organisasi membutuhkan campur 
tangan dari pimpinan dan disiplin kerja dari bawahan itu sendiri.

Tujuan seorang pemimpin adalah melayani kepentingan bawahan yang dipimpinnya, orientasinya adalah bukan untuk kepentingan pribadi maupun golongannya tetapi justru kepentingan organisasi dan kepentingan bawahan yang dipimpinnya. Greenleaf (2002) menyatakan bahwa servant leadership didasarkan pada tanggung jawab utama pada pelayanan terhadap bawahan dengan meletakan kepentingan bawahan diatas kepentingan pemimpin. Penerapan servant leadership dalam organisasi pada dasarnya untuk meningkatkan kinerja bawahan, hal itu sesuai dengan hasil penelitian yang dilakukan oleh Tatilu (2014) yang menyebutkan bahwa penerapan servant leadership memiliki pengaruh terhadap kinerja karyawan dengan keterangan bahwa karakteristik utama yang membeddakan antara kepemimpinan yang melayani dengan model kepemimpinan lainnya adalah keinginan untuk melayani hadir sebelum adanya keinginan untuk memimpin.

Pemimpin yang melayani memiliki perhatian kepada bawahan yang dipimpinnya. Perhatian itu dalam bentuk kepedulian akan kebutuhan, kepentingan, impian dan harapan dari bawahan. Dengan peran pemimpin yang sesuai dengan keinginan bawahan diharapkan akan meningkatkan kesadaran bawahan akan pentingnya disiplin dalam suatu organisasi ini.

Disiplin kerja dapat dilihat sebagai sesuatu yang memiliki manfaat yang besar, baik bagi kepentingan organisasi maupun bagi bawahan itu sendiri. Bagi organisasi adanya disiplin kerja akan menjamin tegaknya tata tertib dan kelancaran pelaksanaan tugas, sehingga memperoleh hasil yang optimal. Adapun bagi bawahan akan diperoleh suasana kerja yang menyenangkan sehingga dapat meningkatkan semangat kerja dalam melaksanakan pekerjaannya (Abidin, 2013). Dengan demikian, bawahan dapat melaksanakan tugasnya dengan penuh kesadaran serta dapat mengembangkan tenaga dan pikirannya semaksimal mungkin demi terwujudnya tujuan organisasi. Penerapan disiplin kerja yang baik akan menjadikan organisasi atau instansi pemerintah mempunyai kinerja yang maksimal dan efektivitas dalam mengerjakan tugas pekerjaan.

Hasil penelitian terdahulu Menurut Barbuto dan Wheeler (2006) dalam Mira dan Margaretha (2012) bahwa kepemimpinan pelayan (servant leadership) merupakan kepemimpinan yang berawal dari perasaan yang tulus yang timbul dari hati yang berkehendak untuk melayani, dimana kepemimpinan tersebut menempatkan kebutuhan karyawan sebagai prioritas utama dan memperlakukan karyawan sebagai rekan kerja sehingga kedekatan diantara pemimpin dan karyawan sangat erat sehingga mampu menimbulkan kepuasan kerja. Menurut (Triludi, 2014) sikap dan tingkah laku bawahan yang menunjukan kesetiaan dan ketaatan terhadap peraturan akan mendukung peningkatan hasil kerja yang baik. Menurut Siagian (2012) bahwa disiplin yang baik mencerminkan tanggung jawab seseorang terhadap tugas-tugas yang diberikan kepadanya sebagai bentuk tingginya kepuasan karyawan dalam bekerja. Menurut Handoko (2012) bahwa kepuasan kerja merupakan penilaian atau cerminan dari perasaan pekerja terhadap pekerjaannya. Besar kecilnya kepuasan kerja karyawan, berhubungan erat dengan kinerja yang dihasilkan.

Instansi pemerintah didirikan dengan tujuan untuk memperoleh dan memberrikan pelayanan maksimal kepada masyarakat. Untuk mewujudkan tujuan instansi tersebut dengan mengoptimalkan komponen komponen dasar organisasi. Ada banyak komponen dasar instansi yaitu terdiri dari alam, modal, sumber daya manusia, teknologi dan keahlian. Kelima komponen dasar tersebut saling terkait dan tidak bisa berdiri sendiri, melainkan harus saling 
mendukung antara satu dengan lainnya demi tercapainya tujuan yang efektif dan efisien. Namun komponen sumber daya manusia adalah yang paling penting, karena manusia adalah penggerak dalam segala aktifitas yang ada dalam organisasi dan kemampuan SDM dapat erus dikembangkan.

Dinas pertanian adalah instansi pemerintah yang beroperasi dalam pengelolaan pertanian tanaman pangan dan hortikultura. Kantor Dinas Pertanian berada disetian Kabupaten Kota yang ada di indonesia. Tujuan Dinas Pertanian yaitu untuk meningkatkan produksi dan produktivitas komoditi tanaman pangan hortikultura dan perkebunan serta untuk meningkatkan penghasilan petani melalui tanaman pangan hortikultura dan perkebunan. Dinas Pertanian merupakan instansi yang berorientasi pada pelayanan publik..

Berdasarkan studi dan fenomena, maka rumusan masalah dalam penelitian ini adalah "Bagaimana meningkatkan kinerja pegawai Dinas Pertanian melalui servant leadership, disiplin kerja, dan kepuasan kerja?. Dengan permasalahan tersebut, maka pertanyaan adalah bagaimana pengaruh servant leadership dan disiplin kerja terhadap kinerja pegawai dengan kepuasan kerja sebagai variabel intervening?

\section{KAJIAN PUSTAKA}

\section{Kinerja Pegawai}

Istilah kinerja berasal darijob performance atau actual performance (prestasi kerja atau prestasi sesungguhnya yang dicapai oleh seseorang), atau juga hasil kerja secara kualitas dan kuantitas yang ingin dicapai oleh seorang pegawai dalam melaksanakan tugasnya sesuai dengan tanggung jawab yang yang diberikan kepadanya. (Mangkunegara, 2007).

Kinerja juga merupakan implementasi dan rencana yang telah disusun organisasi. Implementasi tersebut dilakukan oleh sumber daya manusia yang memiliki kemampuan kompetensi, motivasi, dan kepentingan. Bagaiman organisasi menghargai dan memperlakukan tenaga kerja akan mempengaruhi perilakunya dalam menjalankan kinerja (Wibowo, 2010). Dengan demikian dapat dikatakan bahwa kinerja merupakan hasil prestasi atau hasil kerja yang dapat diukur baik secara kualitatif maupun kuantitatif, serta menggambarkan sejauh mana sebuah organisasi telah berhasil mencapai tujuan yang telah ditetapkannya. Selain itu kinerja juga menunjukan seberapa baik perilaku pegawai dalam upaya menciptakan tujuan organisasi.

Robbins (2006) mengungkapkan beberapa indikator kinerja pegawai yaitu, pertama, kuantitas kerja yang diukur dari jumlah hasil kinerja individu yang telah dicapai. Kedua, kualitas kerja yang diukur dari hasil kerja individu terhadap kualitas pekerjaan yang dihasilkan. Ketiga, ketepatan waktu yaitu menyelesaikan pekerjaan dengan baik sesuai dengan waktu yang telah ditetapkan. Keempat, kemandirian seorang individu yang mampu menyelesaikan pekerjaannya sendiri tanpa bantuan orang lain.

\section{Kepuasan Kerja}

Kepuasan kerja merupakan sikap positif terhadap pekerjaan pada diri seseorang. Pada dasarnya kepuasan kerja merupakan hal yang bersifat individual. Setiap individu akan memiliki tingkat kepuasan yang berbeda-beda sesuai dengan sistem nilai yang berlaku pada dirinya. Biasanya orang akan merasa puas atas kerja yang telah atau sedang dijalankan, apabila apa yang telah dikerjakan dianggap telah memnuhi harapan, sesuai dengan tujuannya dalam bekerja (Robbins \& judge, 2009). Sedangkan menurut Luthan (2006) kepuasan kerja adalah hasil dari persepsi pegawai mengenai seberapa baik pekerjaan mereka memberikan hal yang dinilai penting. Hariandja (2009) menambahkan bahwa kepuasan kerjamerupakan salah satu elemen yang cukup penting dalam 
organisasi. Hal ini disebabkan kepuasan kerja dapat mempengaruhi perilaku kerja seperti malas, rajin, produktif, dan lainlain, ataumempunyai hubungan bebrapa jenis perilaku yang sangat penting dalam organisasi.

Faktor faktor yang mempengaruhi kepuasan kerja menurut Sutrisno (2009) yaitu pertama, kesempatan untuk maju. Kedua, gaji dari pegawai. Ketiga, keaman dalam bekerja. Keempat, organisasi dan manajemen itu sendiri. Kelima, faktor intrinsik dari pekerjaan tersebut. Keenam, pengawasan dalam bekerja. Ketujuh, kondisi tempat kerja. Kedelapan, aspek sosial dalam pekerjaan. Kesembilan, komunikasi. Kesepuluh, fasilitas di tempat kerja.

Indikator yang muncul dari kepuasan kerja yang dikemukakan spector (Yuwono, 2005) yang pertama adalah, kebijakan organisasi. Kedua, promosi. Ketiga, pengawasan/supervisi.. Keempat, rekan kerja.

\section{Servant Leadership}

Servant leadership pertama kali dikonsep oleh Robert K. Greenleaf pada tahun 1970. Karakteristik dari perilaku kepemimpinan yang melayani tumbuh dari nilai-nilai dan keyakinan individu. Nilai-nilai pribadi seperti keadilan dan integritas adalah variabel independen yang menggerakkan perilaku pemimpin yang melayani (Smith, 2005). Menurut Greenleaf, servant leadership adalah suatu gaya kepemimpinan yang berasal dari perasaan tulus yang timbul dari dalam hati yang berkehendak untuk melayani, yaitu menjadi pihak pertama yang melayani (Lantu, 2007). Perbedaannya tampak dalam kepedulian yang ditunjukan oleh seorang pelayan, kesadaran pertama untuk memastikan bahwa kebutuhan orang lain menjadi prioritas untuk dilayani.( Spears \& lawrence, 2004). Pemimpin yang melayani pada akhirnya akan mengembangkan sikap individu disekitarnya dengan harapan memiliki sikap yang sama untuk melayani dengan baik.
Spears (2010) mengemukakan 10 karakteristik servantleader, karakterisitik tersebut yang pertama yaitu, mendengarkan (listening). Kedua, empati (empathy). Ketiga, penyembuhan (healing). Keempat, kesadaran (awareness). Kelima, persuasi (persuatson). Keenam, konseptualisasi (conseptualize). Ketujuh, kejelian (foreseight). Kedelapan, keterbukaan (stewardship). Kesembilan, komitmen untuk pertumbuhan (Commitment to the Growth of People). Kesepuluh, membangun komunitas (building comunity).

Indikator servant leadership menurut Dennis (2004) yang pertama yaitu, kasih sayang (love), kepemimpinan yang mengasihi dengan cinta atau kasih sayang. Cinta yang dimaksud adalah melakukan hal yag benar pada waktu yan tepat untuk alasandan keputusan yang terbaik. Kedua, pemberdayaan (empowerment), penekanan pada kerjasama yaitu mempercayakan kekuasaan pada orang lain, dan mendengarkan saran dari followers. Ketiga Visi (Vision), arah organisasi dimasa mendatang yang akan dibawa oleh seorang pemimpin. Visi akan mengispirasi tindakan dan membantu membentuk masa depan. Keempat, Kerendahan Hati (Humility), menjaga kerendahan hati dengan menunjukkan rasa hormat terhadap pegawai dan mengakui kontribusi pegawai terhadap tim. Kelima, Kepercayaan (Trust), servant-leader adalah orang-orang pilihan yang dipilih berdasarkan suatu kelebihan yang menyebabkan pemimpin tersebut mendapatkan kepercayaan.

\section{Disiplin Kerja}

Menurut Handoko (2001), kedisiplina adalah kegiatan manajemen untuk menjalankan standar-standar organisasi. Sedangkan menurut Rivai (2004), mengungkapkan bahwa kedisiplinan adalah suatu alat yang digunakan oleh para manajer untuk berkomunikasi dengan para pegawai agar mereka bersedia untuk mengubah suatu perilaku serta sebagai 
suatu upaya untuk menignkatkan kesadaran dan kesediaan seseorang menaati semua peraturan organisasi dan norma sosial yang berlaku. Saydam (2005) menambahkan bahwa kedisiplinan adalah sikap kesediaan dan kerelaan seseorang untuk mematuhi dan mentaati segala norma - norma peraturan yang berlaku di sekitarnya. Dari pengertian menurut para ahli diatas dapat disimpulkan bahwa kedisiplinan merupakan alat yang digunakan oleh para manajer, agar pegawai bersedia mentaati dan sadar akan semua peraturan yang berlaku.

Indikator disiplin kerja menurut Soejono (2000) yang pertama yaitu, ketepatan waktu. Para pegawai datang ke kantor tepat waktu, tertib dan, teratur, dengan begitu dapat dikatakan disiplin kerjanya baik. Kedua, menggunakan peralatan kantor dengan baik. Sikap hati-hati dalam menggunakan peralatan kantor dapat mewujudkan bahwa seorang pegawai memiliki disiplin. Ketiga, tanggung jawab yang tinggi. Pegawai yang senantiasa menyelesaika tugas yang dibebankan kepadanyasesuai dengan prosedur dan bertanggung jawab atas hasil kerja, dapat pula dikatakan memiliki disiplin kerja yang baik. Keempat, ketaatan terhadap aturan kantor. Pegawai memakai seragam kantor, menggunakan kartu tanda pengenal/identitas, membuat ijin bila tidak masuk kantor, juga merupakan cerminan dari disiplin kerja yang tinggi.

\section{Kerangka Teoritis dan Pengembangan Hipotesis}

Hubungan Antara Servant leadership Terhadap Kepuasan Kerja

Barbuto dan Wheeler (2006) dalam Mira dan Margaretha (2012) menjelaskan bahwa kepemimpinan pelayan (servant leadership) merupakan kepemimpinan yang berawal dari perasaan yang tulus yang timbul dari hati yang berkehendak untuk melayani, dimana kepemimpinan tersebut menempatkan kebutuhan karyawan sebagai prioritas utama dan memperlakukan karyawan sebagai rekan kerja sehingga kedekatan diantara pemimpin dan karyawan sangat erat sehingga mampu menimbulkan kepuasan kerja.

Hasil penelitian yang dilakukan Saragih, Djastuti, Perdhana (2014) menunjukan bahwa servant leadership berpengaruh positif terhadap kepuasan kerja. Handoyo (2010) menemukan bahwa semakin tinggi komitmen organisasi dalam menerapkan servant leadership, maka akan memberikan dampak yang lebih bagi kepuasan kerja pegawai. Berdasarkan hasil penelitian di atas, hipotesis yang diajukan dalam penelitian ini adalah:

$\mathrm{H} 1$ : Terdapat pengaruh positif antara servant leadership terhadap kepuasan kerja pegawai.

\section{Hubungan Antara Disiplin Kerja Terhadap Kepuasan Kerja}

Siagian (2012) menjelaskan bahwa disiplin yang baik mencerminkan tanggung jawab seseorang terhadap tugas-tugas yang diberikan kepadanya sebagai bentuk tingginya kepuasan karyawan dalam bekerja

Hasil penelitian yang dilakukan oleh Mustafa (2015) menunjukan bahwa disiplin kerja berpengaruh positif terhadap kepuasan kerja, penelitian yang dilakukan masyjui (2005) menunjukan bahwa disiplin kerja berpengaruh terhadap kepuasan kerja. Hal ini menunjukan bahwa pegawai yang memiliki disiplin kerja yang tinggi cenderung memiliki kepuasan kerja yang tinggi pula. Berdasarkan hasil penelitian di atas, hipotesis yang diajukan dalam penelitian ini adalah:

H2: Terdapat pengaruh positif antara disiplin kerja terhadap kepuasan kerja pegawai.

\section{Hubungan Antara Servant Leadership Terhadap Kinerja Pegawai}

Meuser (2011) menjelaskan bahwa servant leadership memiliki dampak yang disukai pada kinerja pengikut dalam peran mereka yaitu cara bawahan melakukan pekerjaan yang ditugaskan. 
Hasil penelitian yang dilakukan Harianto, dkk (2014) menemukan bahwa servant leadership berpengaruh positif terhadap kinerja pegawai dan penelitianyang dilakukan oleh Dewi Urip W; Budiman Christiananta; Anis Eliyana (2014) menunjukan bahwa kinerja pegawai harus di dukung oleh pemimpin yang dapat menyesuaikan diri dalam iklim pekerjaan, pemimpin dalam pendekatan antara manusia menjadi sangat penting, karena pemimpin berperan sebagai pelayan dalam organisasi dan membantu bawahan dalam menyelesaikan pekerjaan dan tanggung jawabnya. Berdasarkan hasil penelitian di atas hipotesis yang diajukan dalam penelitian ini adalah:

$\mathrm{H}_{3}$ : Terdapat pengaruh positif anatara servant leadership terhadap kinerja pegawai.

\section{Hubungan Antara Disiplin Kerja Terhadap Kinerja Pegawai}

Disiplin kerja sangat diperlukan dalam menunjang keberhasilan kinerja pegawai yang maksimal. Hal ini sesuai pernyataan Siagian (2012) bahwa salah satu faktor yang mempengaruhi kinerja karyawan diantaranya adalah karena pentingnya disiplin kerja

Penelitian yang dilakukan oleh Sanjaya (2015) menemukan bahwa disiplin kerja berpengaruh positif terhadap kinerja pegawai. Studi terdahulu yang pernah dilakukan Hasibuan (2002) menunjukan bahwa disiplin yang baik mencerminkan besarnya rasa tanggung jawab seseorang terhadap tugas tugas yang diberikan kepadanya. Hal ini mendorong gairah kerja, semangat kerja dan produktivitas kerja. Berdasarkan hasil penelitian diatas, hipotesis yang akan diajukan dalam penelitian ini adalah:

$\mathrm{H}_{4}$ : Terdapat pengaruh positif antara disiplin kerja terhadap kinerja pegawai.

\section{Hubungan Antara Kepuasan Kerja Terhadap Kinerja Pegawai}

Dalam melaksanakan tugasnya setiap pegawai secara individual mempunyai kepuasan kerja yang berbeda, sekalipun berada dalam tipe pekerjaan yang sama hal ini tergantung tingkat kebutuhannya dan sistem yang berlaku pada dirinya. pegawai yang mampu mengendalikan faktor faktor disiplin kerja akan termotivasi

\section{Model Empirik Penelitian}

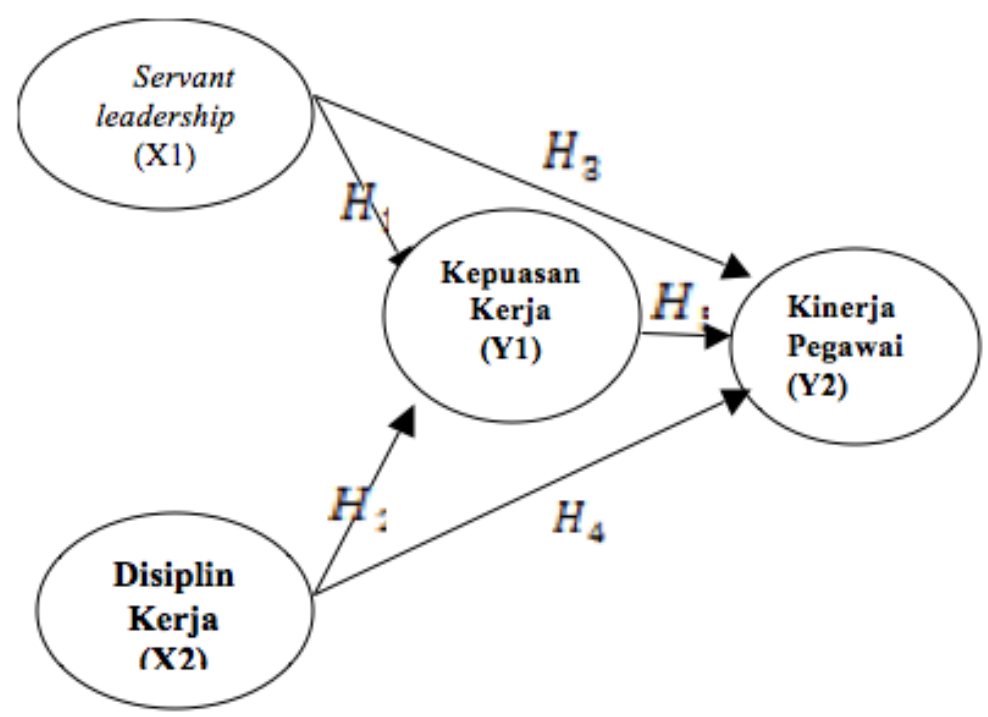


untuk melakukan pekerjaannya dengan baik. Menurut Handoko (2012) bahwa kepuasan kerja merupakan penilaian atau cerminan dari perasaan pekerja terhadap pekerjaannya. Besar kecilnya kepuasan kerja karyawan, berhubungan erat dengan kinerja yang dihasilkan.

Hasil penelitian yang dilakukan Adharianti (2014) menemukan bahwa kepuasan kerja berpengaruh positif terhadap kinerja pegawai, hasil penelitian yang sama juga diperoleh Maryadi (2012). Berdasarkan hasil penelitian di atas, hipotesis yang diajukan dalam penelitian ini adalah:

$\mathrm{H}_{5}$ : Terdapat pengaruh positif antara kepuasan kerja terhadap kinerja pegawai.

\section{METODE PENELITIAN}

\section{Populasi dan Sampel}

Populasi dalam penelitian ini adalah pegawai yang bekerja pada Dinas Pertanian Kabupaten Demak sebanyak 121 orang. Mengacu pada rumus Slovin, maka diperoleh jumlah sampel sebesar 55 pegawai. Teknik pengambilan sampel yang digunakan adalah Proportional Random Sampling. Agar data sampel tersebut bisa mewakili pada masing-masing unit kerja, maka penyebaran dalam penelitian ini dilakukan dengan menggunakan undian.

\section{Metode Analisis Data}

Metode analisa data dilakukan dengan uji analisis kuantitatif dengan alat analisis adalah Path analisis dimana sebelumnya dilakukan uji validitas dan reliabilitas serta uji persyaratan asumsi klasik. Adapun persamaan regresinya dapat ditulis sebagai berikut:

$$
\begin{aligned}
& Y_{1}=\beta_{1} X_{1}+\beta 2 X_{2}+e \\
& Y_{2}=\beta_{3} X_{1}+\beta_{4} X_{2}+\beta_{5} Y_{1}+e
\end{aligned}
$$

Keterangan:

$$
\begin{array}{ll}
\mathrm{Y} & =\text { Kinerja Karyawan } \\
\mathrm{X} 1 & =\text { Servant leadership } \\
\mathrm{X} 2 & =\text { Disiplin Kerja } \\
\mathrm{Y} 1 & =\text { Kepuasan Kerja } \\
\mathrm{Y} 2 & =\text { Kinerja Pegawai } \\
\beta_{: 2,3,4} & =\text { Koefisien Regresi } \\
\mathrm{e} & =\text { Tingkat Kesalahan (error) }
\end{array}
$$

\section{HASIL PENELITIAN DAN PEMBAHASAN Uji Validitas dan Reliabilitas}

Hasil pengujian validitas menunjukkan bahwa semua indikator yang digunakan untuk mengukur instrument pada variabel kepemimpinan, komunikasi internal, kompensasi, disiplin kerja serta kinerja karyawan dinyatakan valid, hal tersebut terlihat dengan nilai $r$ hitungnya telah melebihi nilai $r$ tabel sebesar 0,263.

Pengujian reliabilitas dengan menggunakan rumus Cronbach's Alpha. menunjukkan bahwa variabel kepemimpinan, komunikasi internal, kompensasi, disiplin kerja serta kinerja karyawan memiliki nilai alpha lebih besar dari 0,6. Hasil ini

Tabel 3

Uji Multikolinieritas

\begin{tabular}{llll}
\hline $\begin{array}{l}\text { Variabel } \\
\text { Penelitian }\end{array}$ & \multicolumn{2}{l}{ Collinearity Statistics } & Keterangan \\
& Tolerance & VIF & \\
\hline $\begin{array}{l}\text { Servant } \\
\text { leadership }\end{array}$ & 0,573 & 1,745 & $\begin{array}{l}\text { Tidak terjadi } \\
\text { Problem } \\
\text { multikolinieritas }\end{array}$ \\
$\begin{array}{l}\text { Disiplin kerja } \\
\begin{array}{l}\text { Kepuasan } \\
\text { kerja }\end{array}\end{array}$ & 0,494 & 2,025 & \\
\hline
\end{tabular}


Tabel 2. Normalitas Data

One-Sample Kolmogorov-Smirnov Test

\begin{tabular}{lll} 
& & Unstandardized Residual \\
\hline $\mathrm{N}$ & & 55 \\
\hline $\mathrm{N}$ o r m a & .0000000 \\
Parameters ${ }^{\mathrm{a}, \mathrm{b}}$ & Std. Deviation & 1.56018390 \\
& Absolute & .093 \\
Most Extreme & .073 \\
Differences & Positive & -.093 \\
& Negative & .690 \\
Kolmogorov-Smirnov Z & .727 \\
Asymp. Sig. (2-tailed)
\end{tabular}

a. Test distribution is Normal.

b. Calculated from data.

Tabel 5. Hasil Persamaan Regresi

\begin{tabular}{llllll}
\hline $\begin{array}{l}\text { Variabel } \\
\text { Dependen }\end{array}$ & $\begin{array}{l}\text { Variabel } \\
\text { Independen }\end{array}$ & B & $\begin{array}{l}\text { t } \\
\text { hit }\end{array}$ & Sig & Ket. \\
\hline $\begin{array}{l}\text { Kepuasan } \\
\text { kerja }\end{array}$ & $\begin{array}{l}\text { Servant leadership } \\
\text { Disiplin kerja }\end{array}$ & 0,323 & 2,737 & 0,008 & Ha diterima \\
& 0,487 & 4,126 & 0,000 & Ha diterima \\
Kinerja & Servant leadership & 0,287 & 2,945 & 0,005 & Ha diterima \\
pegawai & Disiplin kerja & 0,225 & 2,147 & 0,037 & Ha diterima \\
& Kepuasan kerja & 0,461 & 4,307 & 0,000 & Ha diterima \\
\hline
\end{tabular}

menunjukkan semua pernyataan (indikator) selanjutnya..

dapat dinyatakan reliabel.

\section{Uji Asumsi Klasik}

\section{Uji Multikolinieritas}

Hasil pengujian multikolinieritas antara servant leadership, disiplin kerja, kepuasan kerja terhadap kinerja pegawai terlihat bahwa semua nilai tolerance menunjukkan di atas 0,10 dan nilai VIF kurang dari 10 yang berarti pengujian tidak terjadi problem multikolinieritas.

\section{Uji Heteroskedastisitas}

Hasil uji heteroskedastisitas terlihat bahwa data menyebar di atas dan di bawah angka 0 pada sumbu Y. Dengan demikian pengujian untuk variabel servant leadership, disiplin kerja dan kepuasan kerja terhadap kinerja pegawai berdistribusi secara normal atau dengan kata lain residual berdistribusi normal, sehingga dapat dilakukan

\section{Uji Normalitas}

Dalam pengujia normalitas ini digunakan normalitas data dengan pertimbangan agar tidak menimbulkan persepsi yang bias.

Hasil pengujian pada variabel pengaruh servant leadership, disiplin kerja dan kepuasan kerja terhadap kinerja pegawai menunjukkan nilai signifikansinya sebesar 0,727 yang berarti telah melebihi tingkat kesalahan sebesar 0,05 yang berarti bahwa Ho diterima dan Ha ditolak. Dengan demikian pengujian pada variabel penelitian memenuhi persyaratan normalitas dan bisa dilanjutkan pada pengujian selanjutnya..

\section{Pengujian Hipotesis}

\section{Pengaruh Servant Leadership terhadap Kepuasan Kerja}

Hasil pengujian servant leadership terhadap kepuasan kerja diperoleh nilai 


\section{Gambar 1. Uji Heteroskedastisitas}

Scatterplot

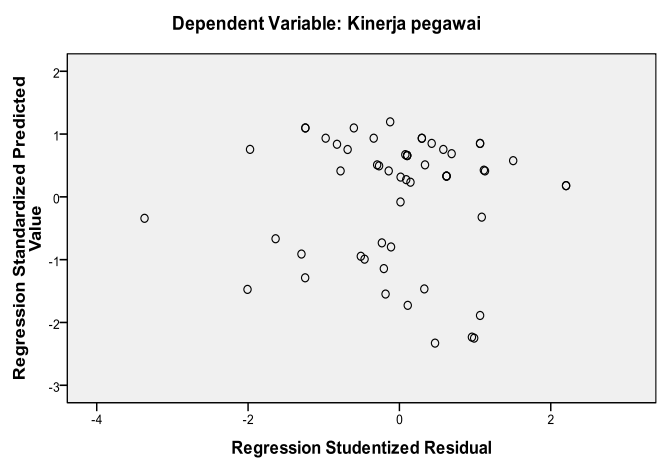

t hitung sebesar 2,737 dengan nilai signifikansi sebesar 0,008 $<0,05$. Pada degree of freedom sebesar $52(n-k-1 ; 55-$ $2-1$ ), diperoleh nilai t tabel sebesar 2,0066 , sehingga nilai t hitung servant leadership sebesar 2,737 telah melebihi dari nilai $t$ tabel 2,0066, yang berarti Ho ditolak dan Ha diterima. Hal ini menunjukkan terdapat pengaruh positif dan signifikan antara servant leadership terhadap kepuasan kerja, sehingga pengujian mampu menerima hipotesis 1. Dengan demikian dugaan yang menyatakan servant leadership mempunyai pengaruh terhadap kepuasan kerja terbukti atau dapat diterima.

\section{Pengaruh Disiplin Kerja terhadap Kepuasan Kerja}

Hasil pengujian disiplin kerja terhadap kepuasan kerja diperoleh nilai $t$ hitung sebesar 4,126 dengan nilai signifikansi sebesar 0,000 yang berarti lebih kecil dari tingkat kesalahan sebesar 0,05. Dengan hasil tersebut, maka nilai $t$ hitung sebesar 4,126 telah melebihi dari nilai $t$ tabel sebesar 2,0066 sehingga Ho ditolak dan Ha diterima.

Dengan hasil tersebut maka disiplin kerja mempunyai pengaruh positif dan signifikan terhadap kepuasan kerja. Hasil pengujian terebut dapat disimpulkan bahwa pengujian mampu menerima hipotesis kedua, sehingga dugaan yang menyatakan adanya pengaruh disiplin kerja terhadap kepuasan kerja terbukti atau dapat diterima.

\section{Pengaruh Servant Leadership terhadap Kinerja Pegawai}

Hasil pengujian servant leadership terhadap kinerja pegawai diperoleh nilai t hitung sebesar 2,945 dengan nilai signifikansi sebesar 0,005 $<0,05$. Pada degree of freedom sebesar $51(n-k-1 ; 55-$ $3-1$ ), diperoleh nilai t tabel sebesar 2,0076, sehingga nilai t hitung sebesar 2,945 > nilai t tabel sebesar 2,0076 yang berarti Ho ditolak dan Ha diterima. Hal ini menunjukkan terdapat pengaruh positif dan signifikan antara servant leadership terhadap kinerja pegawai. Hasil tersebut menunjukkan jika pengujian mampu menerima hipotesis ketiga, sehingga dugaan yang menyatakan adanya pengaruh positif antara servant leadership terhadap kinerja pegawai dapat diterima.

\section{Pengaruh Disiplin Kerja terhadap Kinerja Pegawai}

Hasil pengujian disiplin kerja terhadap kinerja pegawai, diperoleh nilai $t$ hitung sebesar 2,147 dengan hasil signifikansi sebesar 0,037 yang berarti lebih kecil dari batas yang ditentukan sebesar 0,05 . Dengan demikian nilai t hitung sebesar 2,147 > nilai $\mathrm{t}$ tabel $=2,0076$ yang berarti Ho ditolak dan $\mathrm{Ha}$ diteirma, memberikan pengertian jika disiplin kerja mempunyai pengaruh positif dan signifikan terhadap kinerja pegawai. Berdasarkan hasil pengujian menunjukkan bahwa pengujian tersebut mampu menerima hipotesis keempat, sehingga dugaan yang menyatakan adanya pengaruh disiplin kerja terhadap kinerja pegawai terbukti atau dapat diterima.

\section{Pengaruh Kepuasan Kerja terhadap Kinerja Pegawai}

Hasil pengujian kepuasan kerja terhadap kinerja pegawai diperoleh nilai $t$ hitung sebesar 4,307 dengan nilai signifikansi sebesar 0,000 . Hasil tersebut membuktikan jika nilai t hitung sebesar 4,307 telah melebihi 
Tabel 6. Hasil Pengaruh Langsung \& Tdk Langsung

\begin{tabular}{|c|c|c|c|}
\hline Variabel & Pengaruh & $\begin{array}{l}\text { Hasil } \\
\text { Perhitungan }\end{array}$ & Ket. \\
\hline $\begin{array}{l}\text { Servant } \\
\text { leadership } \\
\left(\mathrm{X}_{1}\right)\end{array}$ & $\begin{array}{l}\text { Pengaruh } \\
\text { Langsung } \\
\text { Tidak } \\
\text { Langsung }\end{array}$ & $\begin{array}{l}0,287 \\
(0,323 \times 0,461) \\
=0,149\end{array}$ & $\begin{array}{l}\text { Tidak mampu } \\
\text { menjadi variable } \\
\text { intervening }\end{array}$ \\
\hline $\begin{array}{l}\text { Disiplin } \\
\text { kerja } \\
\left(\mathrm{X}_{2}\right)\end{array}$ & $\begin{array}{l}\text { Pengaruh } \\
\text { Langsung } \\
\text { Tidak } \\
\text { Langsung }\end{array}$ & $\begin{array}{l}0,225 \\
(0,487 \times 0,461) \\
=0,225\end{array}$ & $\begin{array}{l}\text { Mampu } \\
\text { menjadi variable } \\
\text { intervening }\end{array}$ \\
\hline
\end{tabular}

dari nilai $\mathrm{t}$ tabel sebesar 2,0076, yang berarti Ho ditolak dan Ha diterima sehingga memberikan pengertian bahwa kepuasan kerja mempunyai pengaruh positif dan signifikan terhadap kinerja pegawai. Dengan demikian pengujian mampu menerima hipotesis kelima, sehingga dugaan yang menyatakan adanya pengaruh kepuasan kerja terhadap kinerja pegawai terbukti atau dapat diterima.

\section{Pengaruh Langsung dan Tidak Langsung}

Untuk mengetahui kepuasan kerja mampu memediasi hubungan antara servant leadership dan disiplin kerja terhadap kinerja pegawai, maka harus dihitung terlebih dahulu antara pengaruh tidak langsung dan langsungnya, seperti dijelaskan pada table berikut:

\section{Pengaruh Servant Leadership Terhadap Kinerja Pegawai melalui Kepuasan Kerja}

Hasil perhitungan perkalian untuk pengaruh tidak langsung antara servant leadership terhadap kepuasan kerja menuju ke kinerja pegawai diperoleh nilai sebesar 0,149 , sedangkan pengaruh langsung antara servant leadership terhadap kinerja pegawai diperleh sebesar 0,287 , yang berarti bahwa total pengaruh tidak langsung 0,149 < pengaruh langsung 0,287 dapat diartikan bahwa kepuasan kerja tidak mampu menjadi variabel intervening antara servant leadership dengan kinerja pegawai. Dengan demikian servant leadership hanya berpengaruh terhadap kinerja pegawai saja tetapi tidak harus melalui kepuasan kerja.

\section{Pengaruh Disiplin Kerja terhadap Kinerja Pegawai melalui Kepuasan Kerja}

Hasil pengujian mediasi diperoleh nilai untuk pengaruh tidak langsung antara disiplin kerja terhadap kepuasan kerja menuju ke kinerja pegawai diperoleh nilai sebesar 0,225 , sedangkan pengaruh langsung antara disiplin kerja terhadap kinerja pegawai juga menunjukkan hasil yang sama yaitu sebesar 0,225 , yang berarti bahwa pengaruh tidak langsung 0,225 $\geq$ pengaruh langsung 0,225 yang berarti bahwa kepuasan kerja mampu menjadi variabel intervening antara disiplin kerja terhadap kinerja pegawai.

\section{PEMBAHASAN}

\section{Pengaruh Servant Leadership terhadap Kepuasan Kerja}

Servant leadership ditemukan berpengaruh positif dan signifikan terhadap kepuasan kerja, dapat diartikan bahwa semakin tinggi servant leadership, maka semakin pemimpin mampu melayani bawahannya dengan tulus, sehingga akan mempengaruhi tingginya kepuasan kerja pegawai. Pegawai akan merasa puas jika pemimpin menganggap tidak ada batasan antara bawahan dengan atasan ketika bergaul, akan tetapi dalam pekerjaan tetap mengedepankan sikap professional dalam pekerjaan. Pemimpin akan dihargai oleh bawahannya apabila dalam kepemimpinannya memberikan peluang- 
peluang untukmemberdayakan bawahannya dengan baik dalam memajukan organisasi. Apalagi ditunjang jika pemimpin mempunyai pemikiran yang visioner yang jelas dalam memajukan organisasi, tentu akan semakin menambah tingginya kepuasan kerja.

Pemimpin harus lebih berfokus pada pemberian pelayanan kepada orang lain dengan bersinergi kepada bawahan dalam bekerja yaitu dengan tetap menganggap keberadaan bawahan, sehingga akan menimbulkan rasa kebersamaan untuk dapat saling berbagi ketika mengambil suatu keputusan. Untuk itulah diperlukan kepercayaan yang tinggi dalam diri pegawai dengan segala keputusan yang diambil oleh atasan.

Menurut Barbuto dan Wheeler (2006) dalam Mira dan Margaretha (2012) bahwa kepemimpinan pelayan (servant leadership) merupakan kepemimpinan yang berawal dari perasaan yang tulus yang timbul dari hati yang berkehendak untuk melayani, dimana kepemimpinan tersebut menempatkan kebutuhan karyawan sebagai prioritas utama dan memperlakukan karyawan sebagai rekan kerja sehingga kedekatan diantara pemimpin dan karyawan sangat erat sehingga mampu menimbulkan kepuasan kerja. Hasil penelitian ini mendukung hasil temuan Handoyo (2010), Zaluchu (2011), dan Saragih, Djastuti, Perdhana (2014) bahwa servant leadership berpengaruh positif terhadap kepuasan kerja. Akan tetapi hasil penelitian ini tidak mendukung hasil temuan Damara (2015) bahwa servant leadership justru tidak berpengaruh terhadap kepuasan kerja.

\section{Pengaruh Disiplin Kerja terhadap Kepuasan Kerja}

Hasil penelitian terbukti bahwa disiplin kerja mempunyai pengaruh positif dan signifikan terhadap kepuasan kerja, memberikan pengertian bahwa semakin tinggi disiplin kerja pegawai, maka menunjukkan tingginya tingkat kepuasan kerja pegawai. Karyawan yang mempunyai tingkat kepuasan yang tinggi akan berusaha untuk berangkat ke kantor tepat waktu. Apalagi jika pihak organisasi menyediakan peralatan atau fasilitas yang baik dalam menunjang pekerjaan.

Disiplin kerja terbentuk karena tingginya tanggung jawab dari pegawai atas hasil kerja yang di kerjakan. Pegawai yang mempunyai tingkat kepuassan yang tinggi akan berusaha bertanggung jawab terhadap apa yang dikerjakannya. Hal tersebut karena dengan adanya disiplin yang baik dari pegawai, maka mencerminkan tingginya tanggung jawab pegawai terhadap tugas yang diberikannya. Perhatian pihak manajemen dalam memperhatikan kepuasan pegawai tentu akan dipengaruhi oleh ketaatan pegawai terhadap aturan aturan yang telah ditetapkan oleh pihak organisasi.

Menurut Siagian (2012) bahwa disiplin yang baik mencerminkan tanggung jawab seseorang terhadap tugas-tugas yang diberikan kepadanya sebagai bentuk tingginya kepuasan karyawan dalam bekerja. Hasil penelitian ini mendukung hasil temuan Mustafa (2015), Masyjui (2005) dan Barista (2015) yang menunjukkan bahwa disiplin kerja berpengaruh positif terhadap kepuasan kerja. Akan tetapi hasil temuan yang dilakukan oleh Taroreh (2014) menunjukkan jika disiplin kerja tidak berpengaruh terhadap kepuasan dan kinerja pegawai.

\section{Pengaruh Servant Leadership terhadap Kinerja Pegawai}

Hasil penelitian menunjukkan bahwa terdapat pengaruh positif dan signifikan antara servant leadership terhadap kinerja pegawai, dapat diartikan bahwa semakin tinggi servant leadership, maka semakin pemimpin mampu melayani bawahannya dengan tulus, sehingga hal itu akan berdampak pada tingginya kinerja pegawai. Kinerja pegawai akan meningkat jika pemimpin menganggap tidak ada batasan antara bawahan dengan atasan ketika bergaul, akan tetapi dalam pekerjaan 
tetap mengedepankan sikap professional dalam pekerjaan. Pemimpin akan dihargai oleh bawahannya apabila dalam kepemimpinannya memberikan peluangpeluang untukmemberdayakan bawahannya dengan baik dalam memajukan organisasi dalam memajukan kinerja pegawai secara maksimal. Untuk itulah peran pemimpin yang mempunyai pemikiran yang visioner yang jelas dalam memajukan organisasi sangat diperlukan dalam meningkatkan kinerja pegawai secara maksimal. Dengan visi organisasi public, maka sebagai pelayan masyarakat pemimpin dapat membuat visi guna memperbaharui sikap, perilaku serta pendapat.

Keterlibatan pemimpin untuk lebih berfokus pada pemberian pelayanan kepada orang lain dengan bersinergi kepada bawahan dalam bekerja sangat diperlukan dalam pencapaian kinerja pegawai secara maksimal, yaitu dengan tetap menganggap keberadaan bawahan, sehingga akan menimbulkan rasa kebersamaan untuk dapat saling berbagi ketika mengambil suatu keputusan. Untuk itulah diperlukan kepercayaan yang tinggi dalam diri pegawai dengan segala keputusan yang diambil oleh atasan.

Menurut Meuser (2011) bahwa servant leadership memiliki dampak yang disukai pada kinerja pengikut dalam peran mereka yaitu cara bawahan melakukan pekerjaan yang ditugaskan. Penelitian ini mendukung hasil temuan Harianto, dkk (2014) dan Dewi, dkk (2014) menemukan bahwa servant leadership berpengaruh positif terhadap kinerja pegawai. Akan tetapi hasil penelitian ini tidak mendukung hasil temuan Adharianti (2014) bahwa servant leadeershipt tidak berpengaruh terhadap kinerja pegawai.

\section{Pengaruh Disiplin Kerja terhadap Kinerja Pegawai}

Disiplin kerja terbukti mempunyai pengaruh positif dan signifikan terhadap kinerja pegawai, memberikan pengertian bahwa semakin tinggi disiplin kerja pegawai, maka tentu akan mempengaruhi tingginya kinerja pegawai. Kinerja pegawai dapat meningkat jika para pegawai berangkat ke kantor tepat waktu. Hal ini sangat diperlukan karena dengan mematuhi aturan yang telah ditetapkan pihak organisasi untuk dating tepat waktu, tentu akan mempengaruhi kinerja pegawai secara maksimal. Untuk itulah diperlukan factor penunjang seperti tersedianya peralatan atau fasilitas yang baik sehingga akan mampu mempengaruhi kinerja pegawai secara maksimal.

Disiplin kerja terbentuk karena tingginya tanggung jawab dari pegawai atas hasil kerja yang di kerjakan. Semakin tinggi tanggung jawab dari pegawai atas hasil kerja yang dikerjakan, tentu akan semakin meningkatkan kinerja pegawai secara maksimal. Hal tersebut karena dengan adanya disiplin yang baik dari pegawai, maka mencerminkan tingginya tanggung jawab pegawai terhadap tugas yang diberikannya dalam pencapaian kinerja yang maksimal. Untuk itulah diperlukan ketaatan yang tinggi dalam diri pegawai terhadap aturan aturan yang telah ditetapkan oleh pihak organisasi dalam upaya pencapaian kinerja secara maksimal.

Menurut Siagian (2012) bahwa salah satu factor yang mempengaruhi kinerja karyawan diantaranya adalah karena pentingnya disiplin kerja. Hasil penelitian ini mendukung hasil temuan Sanjaya (2015) menemukan bahwa disiplin kerja berpengaruh positif terhadap kinerja pegawai. Akan tetapi hasil temuan yang dilakukan oleh Taroreh (2014) menunjukkan jika disiplin kerja tidak berpengaruh terhadap kinerja pegawai.

\section{Pengaruh Kepuasan Kerja terhadap Kinerja Pegawai}

Hasil penelitian terbukti bahwa kepuasan kerja berpengaruh positif dan signifikan terhadap kinerja pegawai, mempunyai arti bahwa semakin tinggi tingkat kepuasan kerja pegawai, maka tentu akan berdampak pada tingginya kinerja pegawai. Kinerja pegawai dapat maksimal jika pegawai 
merasakan kepuasan terhadap kebijakan yang telah ditetapkan organisasi. Untuk itulah diperlukan perhatian dari pihak manajemen dalam memperhatikan pegawai, antara lain perhatian terhadap kebijakan promosi (kenaikan pangkat atau jabatan) sehingga kinerja pegawai yang dihasilkan akan meningkat.

Faktor lain yang tak kalah penting dalam meningkatkan kinerja pegawai diantaranya peran pentingnya pihak pimpinan dalam memberikan arahan yang benar kepada para bawahannya. Peran pentingnya atasan sangat dibutuhkan dalam mengarahkan kepada bawahan yaitu berusaha untuk lebih mengedepankan kerja sama dengan mendukung sesama rekan kerja dalam upaya meningkatkan kinerja pegawai secara maksimal.

Menurut Handoko (2012) bahwa kepuasan kerja merupakan penilaian atau cerminan dari perasaan pekerja terhadap pekerjaannya. Besar kecilnya kepuasan kerja karyawan, berhubungan erat dengan kinerja yang dihasilkan. Penelitian ini mendukung hasil temuan Mulyadi (2012) dan Adharianti (2014) yang menemukan bahwa kepuasan kerja berpengaruh positif terhadap kinerja pegawai. Sedangkan hasil penelitian Barista (2015) terjadi sebaliknya bahwa kepuasan kerja tidak berpengaruh terhadap kinerja pegawai.

\section{Pengaruh Langsung dan Tidak Langsung}

Hasil penelitian kepuasan kerja tidak mampu menjadi variabel intervening antara servant leadership terhadap kinerja pegawai. Dengan demikian servant leadership hanya berpengaruh terhadap kinerja pegawai saja tidak harus melalui kepuasan kerja. Dengan demikian semakin pemimpin mampu melayani bawahannya dengan tulus, maka hanya mampu meningkatkan kinerja pegawai secara maksimal.

Kepuasan kerja mampu menjadi variable intervening antara disiplin kerja terhadap kinerja pegawai, dapat diartikan bahwa semakin tinggi disiplin kerja pegawai, maka menunjukkan tingginya tingkat kepuasan kerja sehingga tentu akan berdampak pada tingginya kinerja pegawai secara maksimal. Pegawai yang puas tentu akan berusaha untuk disiplin, yaitu berusaha bekerja untuk tepat waktu, menggunakan peralatan kantor dengan baik, mempunyai tanggung jawab yang tinggi dan mempunyai ketaatan yang tinggi terhadap aturan yang telah ditetapkan oleh organisasi sehingga tentu akan mempengaruhi kinerja pegawai secara maksimal

\section{SIMPULAN}

Servant leadership terbukti berpengaruh positif dan signifikan terhadap kepuasan kerja, dapat diartikan bahwa semakin tinggi servant leadership, maka semakin pemimpin mampu melayani bawahannya dengan tulus, sehingga akan mempengaruhi tingginya kepuasan kerja pegawai.

Disiplin kerja mempunyai pengaruh positif dan signifikan terhadap kepuasan kerja, memberikan pengertian bahwa semakin tinggi disiplin kerja pegawai, maka menunjukkan tingginya tingkat kepuasan kerja pegawai..

Servant leadership terbukti mempunyai pengaruh positif dan signifikan terhadap kinerja pegawai, dapat diartikan bahwa semakin tinggi servant leadership, maka semakin pemimpin mampu melayani bawahannya dengan tulus, sehingga hal itu akan berdampak pada tingginya kinerja pegawai.

Disiplin kerja terbukti mempunyai pengaruh positif dan signifikan terhadap kinerja pegawai, memberikan pengertian bahwa semakin tinggi disiplin kerja pegawai, maka tentu akan mempengaruhi tingginya kinerja pegawai.

Kepuasan kerja berpengaruh positif dan signifikan terhadap kinerja pegawai, mempunyai arti bahwa semakin tinggi tingkat kepuasan kerja pegawai, maka tentu akan berdampak pada tingginya kinerja pegawai.

Kepuasan kerja mampu menjadi variabel 
intervening antara servant leadership terhadap kinerja pegawai, artinya semakin tinggi servant leadership, maka semakin pemimpin mampu melayani bawahannya dengan tulus, sehingga akan mempengaruhi tingginya kepuasan kerja dan kinerja pegawai secara maksimal.

Kepuasan kerja mampu menjadi variable intervening antara disiplin kerja terhadap kinerja pegawai, dapat diartikan bahwa semakin tinggi disiplin kerja pegawai, maka menunjukkan tingginya tingkat kepuasan kerja sehingga tentu akan berdampak pada tingginya kinerja pegawai secara maksimal.

Atas dasar kesimpulan yang telah dikemukakan di atas, dapat diberikan beberapa saran dan diharapkan dapat berguna bagi kemajuan perusahaan. Adapun beberapa saran tersebut adalah :

Hendaknya ada upaya visi yang jelas dari dalam diri pemimpin yaitu dengan melakukan komunikasi secara intensif sehingga dapat menyatukan visi yang jelas antara bawahan dan atasan dalam pencapaian kinerja secara maksimal. Hal ini bisa dilakukan dengan cara melaksanakan gathering setiap enam bulan atau satu tahun sekali yang berisi pemberian motivasi dan permainan-permainan seru yang bisa melatih kekompakan antar pegawai. Selain itu dalam gathering ini pemimpin bisa secara langsung bertatap muka dengan bawahan serta menyampaikan visinya secara jelas kepada bawahannya.

Hendaknya ada aturan yang tegas dalam mendukung kedisiplinan dalam diri pegawai, yaitu dengan memberikan sangsi pemotongan uang kehadiran ataupun pemotongan bonus bagi pegawai yang terlambat, membolos masuk kerja, meninggalkan kantor sehingga akan membuat kinerja pegawai akan lebih maksimal.

Hendaknya ada upaya dari pihak pimpinan untuk mengupayakan agar terjalin kerja sama antar rekan kerja, yang membuat pekerjaan bisa dilakukan dengan cepat dan terjalin hubungan yang baik antar rekan kerja

Pada penelitian selanjutnya sebaiknya perlu menambah variabel penelitian intrinsic motivation agar dapat meningkatkan peneitian yang lebih baik lagi.

Pada penelitian selanjutnya sebaik ditambah dengan teknik wawancara sehingga akan lebih memperkuat keakuratan data.

\section{DAFTAR PUSTAKA}

Handoko, T. Hani. (2001). Manajemen Personalia dan Sumber Daya Manusia. BPFE : Yogyakarta.

Harianto. Dkk. (2014). Pengaruh Servant Leadership Terhadap Kinerja Pegawai Melalui Disiplin Kerja Pada Dinas Pekerjaan Umum (PU) Pengairan kabupaten banyuwangi.

Hasibuan, Melayu SP. (2003). Manajemen Sumber Daya Manusia, Edisi Revisi. Bumi Aksara : Jakarta.

Mangkunegara, A, P. (2010). Manajemen Sumber Daya Manusia Perusahaan. Bandung: PT Remaja Rosdakarya.

Mustafa. (2015). Pengaruh Kompensasi dan Disiplin Kerja Terhadap Kepuasan Kerja Serta Implikasinya Kepada Kinerja Dosen Di Sekolah Tinggi Pariwisata Bandung.

Rivai. (2004). Manajemen Sumber Daya Manusia Untuk Perusahaan: Dari Teori Ke Praktik. Jakarta: PT. Raja Grafindo Persada

Spears, L.C \& Lawrence, M. (2004). "Servant Leadership: Succeeding through Trust, Bravery, and Forgiveness". USA: Jossey-Bass

Sutrisno, Edy. (2009). Manajemen Sumber Daya Manusia. Kencana: Jakarta 